\title{
Comparative analysis of predictive significance of neuroimaging parameters in patients with spontaneous supratentorial intracerebral hemorrhage
}

\author{
A. A. Kuznietsov \\ Zaporizhzhia State Medical University, Ukraine
}

The main purpose of the study was to conduct a comparative analysis of the neuroimaging parameters informative value for the determination of vital and functional outcomes prognosis of the spontaneous supratentorial intracerebral hemorrhage (SSICH) in the acute period, depending on the secondary intraventricular hemorrhage (SIVH) presence or absence at the disease onset.

Materials and methods. A prospective cohort study was conducted in 154 patients (88 men and 66 women, mean age $64.4 \pm 0.9$ years) with SSICH on the basis of conservative treatment. This study included clinical assessment and visualization of cerebral structures. Intracerebral hemorrhage volume (ICHV), average midline shift (AMS) and intraventricular hemorrhage volume (IVHV) were detected. The modified Rankin Scale (mRS) score $>3$ on the $21^{\text {st }}$ day of the disease was considered as an unfavourable functional outcome of SSICH in the acute period.

Results. Secondary intraventricular hemorrhage was revealed in $70(45.5 \%)$ patients. It was found that ICHV was less informative than IVHV in patients with SIVH for the vital outcome prognosis of disease in the acute period determination ( $\mathrm{AUC}_{\text {ICHV }}=0.72 \pm 0.09$ $(0.60-0.82)$ versus $\left.A U C_{I V H V}=0.94 \pm 0.04(0.86-0.98), P=0.026\right)$, whereas the informative value of ICH volume and AMS were not significantly different in patients without SIVH for the vital outcome prognosis determination (AUC $\mathrm{C}_{\text {ICHV }}=0.77 \pm 0.11(0.67-0.86)$ versus $\left.\mathrm{AUC}_{\text {AMS }}=0.87 \pm 0.05(0.78-0.94), \mathrm{P}=0.257\right)$ in the acute period of disease. It was detected, that IVHS $>24.5 \mathrm{~mL}$ was the predictor of SSICH lethal outcome in the acute period ( $\mathrm{Se}=84.6 \%, \mathrm{Sp}=96.5 \%$ ).

Conclusions. Predictive value of the neuroimaging parameters at SSICH onset depends on SIVH presence or absence. Intracerebral hemorrhage volume is less informative than IVHV and AMS for the vital and functional outcomes prognosis determination in the acute period of SSICH with SIVH. The informative value of neuroimaging parameters for the vital outcome prognosis of $\mathrm{SSICH}$ in the acute period determination is higher than the one for the functional prognosis determination.

\section{Порівняльний аналіз інформативності нейровізуалізаційних параметрів у пацієнтів зі спонтанним супратенторіальним внутрішньомозковим крововиливом}

\section{А. А. Кузнєцов}

Мета роботи - здійснити диференційований порівняльний аналіз інформативності нейровізуалізаційних параметрів для визначення вітального та функціонального прогнозу результату гострого періоду спонтанного супратенторіального внутрішньомозкового крововиливу (ССВМК) залежно від наявності чи відсутності вторинного внутрішньошлуночкового крововиливу (ВВШК) у дебюті захворювання.

Матеріали та методи. Здійснили проспективне, когортне дослідження 154 пацієнтів (88 чоловіків і 66 жінок, середній вік - 64,4 \pm 0,9 року) зі ССВМК, які отримували консервативну терапію. Дослідження включало клінічне дослідження та візуалізацію церебральних структур. Визначали об'єм внутрішньомозкового крововиливу (ОВМК), середнє зміщення серединних структур (СЗСС) та об'єм внутрішньошлуночкового крововиливу (ОВШК). Як несприятливий функціональний вихід гострого періоду ССВМК розглядали значення за модифікованою шкалою Ренкіна (мШР) >3 бали на 21 добу захворювання.

Результати. Вторинний внутрішньошлуночковий крововилив зафіксували у $70(45,5 \%)$ пацієнтів. Встановили, що в пацієнтів зі ССВМК і ВВШК ОВМК поступається за інформативністю ОВШК і СЗСС для визначення вітального прогнозу результату гострого періоду захворювання (AUC ${ }_{\text {овмк }}=0,72 \pm 0,09(0,60-0,82)$ проти $\left.\mathrm{AUC}_{\text {овшк }}=0,94 \pm 0,04(0,86-0,98), \mathrm{p}=0,026\right)$, а в пацієнтів зі ССВМК без ВВШК ОВМК і СЗСС вірогідно не відрізняються за інформативністю для прогнозування летального наслідку $\left(\mathrm{AUC}_{\mathrm{oвмк}}=0,77 \pm 0,11(0,67-0,86)\right.$ проти $\left.\mathrm{AUC}_{\mathrm{cзсс}}=0,87 \pm 0,05(0,78-0,94), \mathrm{p}=0,257\right)$. Встановили, що ОВШК $>24,5$ мл є предиктором летального наслідку гострого періоду ССВМК (чутливість $=84,6$ \%, специфічіність $=96,5 \%$ ).

Висновки. Прогностична цінність нейровізуалізаційних параметрів у дебюті ССВМК залежить від наявності чи відсутності ВВШК. Об'єм внутрішньомозкового крововиливу поступається за інформативністю ОВШКі СЗСС для визначення вітального та функціонального прогнозу результату гострого періоду ССВМК зі ВВШК. Інформмативність нейровізуалізаційнихпараметрів для визначення вітального прогнозу наслідків гострого періоду ССВМКперевищує таку для прогнозування функціонального виходу.

\section{Сравнительный анализ прогностической ценности нейровизуализационных параметров у пациентов со спонтанным супратенториальным внутримозговым кровоизлиянием}

\section{А. А. Кузнецов}

Цель работы - провести сравнительный анализ информативности нейровизуализационных параметров для определения витального и функционального прогноза исхода острого периода спонтанного супратенториального внутримозгового кровоизлияния (ССВМК) в зависимости от наличия или отсутствия вторичного внутрижелудочкового кровоизлияния (ВВЖК) в дебюте заболевания. 
Запорожский медицинский журнал. - 2018. -

T. 20, № 4(109). C. $543-547$
Материалы и методы. Проведено проспективное, когортное исследование 154 пациентов (88 мужчин и 66 женщин, средний возраст - 64,4 \pm 0,9 года) со ССВМК, которые получали консервативную терапию. Исследование включало клиническое обследование и визуализацию церебральных структур. Определяли объем внутримозгового кровоизлияния (ОВМК), усредненное смещение срединных структур (УССС) и объем внутрижелудочкового кровоизлияния (ОВЖК). В качестве неблагоприятного функционального исхода острого периода ССВМК рассматривали значение по модифицированной шкале Рэнкина (мШР) >3 баллов на 21 сутки заболевания.

Результаты. Вторичное внутрижелудочковое кровоизлияние зафиксировано у 70 (45,5\%) пациентов. Установлено, что у пациентов с ССВМК и ВВЖК ОВМК уступает по информативности ОВЖК и УССС для определения витального прогноза исхода острого периода заболевания (AUC ${ }_{\text {овмк }}=0,72 \pm 0,09(0,60-0,82)$ против $\mathrm{AUC}_{\text {овжк }}=0,94 \pm 0,04(0,86-0,98)$, p = 0,026), тогда как у пациентов с ССВМК без ВВЖК ОВМК и УССС достоверно не отличаются по информативности для прогнозирования летального исхода $\left(\mathrm{AUC}_{\text {овмк }}=0,77 \pm 0,11(0,67-0,86)\right.$ против $\left.\mathrm{AUC}_{\text {уссс }}=0,87 \pm 0,05(0,78-0,94), \mathrm{p}=0,257\right)$. Определено, что ОВЖК >24,5 мл выступает предиктором летального исхода острого периода ССВМК (чувствительность $=84,6 \%$, специфричность $=96,5 \%)$.

Выводы. Прогностическая ценность нейровизуализационных параметров в дебюте ССВМК зависит от наличия или отсутствия ВВЖК. Объем внутримозгового кровоизлияния уступает по информативности ОВЖК и УССС для определения витального и функционального исхода острого периода ССВМК с ВВЖК. Информативность нейровизуализационных параметров для определения витального прогноза исхода острого периода ССВМК превышает таковую для прогнозирования функционального исхода.

\section{Introduction}

Cerebral hemorrhagic stroke is the most severe form of acute cerebral circulation disorders, which is characterized with high rates of mortality and disability of the adult population in most countries of the world [3,8,11]. Spontaneous supratentorial intracerebral hemorrhages $(\mathrm{SSICH})$ are the most common in the structure of cerebral hemorrhagic stroke $[1,9]$.

The choice of optimal treatment tactics for patients with $\mathrm{SSICH}$ is one of the most complicated and, unfortunately, yet unsolved problems of modern angioneurology. The aforementioned justifies the reasonability of studies aimed at the research of parameters associated with the outcome of disease in the acute period in order to further develop the criteria for short-term prognosis verification as the basis for making differentiated therapeutic and tactical solutions [12].

Nowadays, the influence of cerebral structures damage severity over the course and outcome of disease in the acute period is convincingly proved [14]. At the same time, $\mathrm{SSICH}$ is a pathomorphologically heterogeneous process $[2,6,15,18]$. In $40-50 \%$ of cases SSICH is accompanied by the following complication: the blood breakthrough into the brain ventricular system $[4,7,16]$. All of the above justifies the reasonability of the neuroimaging criteria predictive value differentiated evaluation for the cerebral structures damage severity assessment in patients with $\mathrm{SSICH}$, taking into consideration the pathomorphological heterogeneity of the pathological process.

\section{The purpose}

The main purpose of this study was to conduct a comparative analysis of the neuroimaging parameters informative value for the vital and functional outcomes prognosis of spontaneous supratentorial intracerebral hemorrhage in the acute period determination depending on the secondary intraventricular hemorrhage presence or absence at the disease onset.

\section{Materials and methods}

In order to achieve the goal a prospective, cohort, comparative study was conducted in 154 patients ( 88 men and 66 women, mean age $64.4 \pm 0.9$ years) with SSICH confirmed by the clinical and neuroimaging study results. They were admitted to Acute Brain Circulation Disorders Department within the first 24 hours of the disease onset. The study excluded patients who had acute cerebrovascular accident in the anamnesis, several lesions, decompensated somatic pathology, oncological pathology, indications for surgical treatment in accordance with the neurosurgical examination results. Cases of death due to extracerebral causes in accordance with the autopsy results were excluded from the analysis.

Clinical and neurological study included the neurological deficit level assessment using the National Institute of Health Stroke Scale (NIHSS), Glasgow Coma Scale (GCS) and Full outline of UnResponsiveness (FOUR) Scale in the acute period dynamics. A computed tomography study was conducted on admission with the help of a multislice computed tomography scanner «Siemens Somatom Spirit». Intracerebral hemorrhage volume (ICHV) was calculated using the ellipsoid formula: ICHV $=\left(a^{*} b^{*} c\right) / 2$, where $a, b$, $c$ are lesion linear sizes $(\mathrm{cm})$. The dislocation syndrome severity was assessed based on septum pellucidum displacement (SPD) and pineal gland displacement (PGD). The average midline shift (AMS) was used for an integrated estimation of the median brain structures lateral displacement: $A M S=(S P D+P G D) / 2$. The severity of secondary intraventricular hemorrhage was assessed in accordance with the Intraventricular hemorrhage scale (IVHS), which takes into consideration different gradations of blood volume in brain ventricles, the presence / absence of hydrocephalus and the distortion of the lateral volume of the III and IV brain ventricles. Intraventricular hemorrhage volume (IVHV) was calculated using the formula: IVHV $=\mathrm{e}^{\wedge}(\mathrm{IVHS}$ score/5).

All patients underwent conservative therapy in accordance with the Unified Clinical Protocol for the provision of medical care to patients with cerebral hemorrhagic stroke, approved by the order of the Ministry of Health of Ukraine No. 275 of April 17, 2014 [1]. The modified Rankin Scale (mRS) score $>3$ on the $21^{\text {st }}$ day of the disease was considered as an unfavourable functional outcome of acute SSICH period.

Statistical analysis of the results was made with the help of Statistica 6.0 (StatSoft Inc., USA, series number 
AXXR712D833214FAN5) and MedCalc (version 16.4) software. The studied parameters were assessed for normality using the Shapiro-Wilk criterion. Descriptive statistics are presented in the form of $\mathrm{M} \pm \mathrm{m}$ for values with normal distribution and in the form of median (Me) and interquartile range (IQR) due to non-normal distribution of parameters. Comparative ROC analysis was used to compare the predictive value of neuroimaging parameters. Cut-off values were determined along with an optimum ratio of sensitivity (Se) and specificity (Sp). A P-value of $<0.05$ was defined as statistically significant.

\section{Results of the study}

Secondary intraventricular hemorrhage (SIVH) was revealed in $70(45.5 \%)$ patients.

Clinical and neuroimaging characteristics of the com- mon cohort of patients regarding the SIVH presence or absence are represented in Table 1.

Clinical and neuroimaging characteristics of the sub-cohorts of examined patients with regard to the vital and functional outcomes of the disease in the acute period are represented in Tables 2 and 3.

The results of the neuroimaging parameters informative value assessment for the vital and functional outcomes prognosis of disease in the acute period determination in patients with SSICH and SIVH are displayed in Tables 4 and 5.

As shown in Tables 4 and 5, SIVH volume and indexes which demonstrate the dislocation syndrome severity are the most informative neuroimaging parameters for the vital and functional outcomes determination in the acute period of SSICH with SIVH.

On the basis of comparative ROC analysis it was estimated that $\mathrm{ICH}$ volume was less informative than

Table 1. Clinical and neuroimaging characteristics of the examined patients

\begin{tabular}{|c|c|c|c|}
\hline Parameters & Common cohort $(n=154)$ & Patients without SIVH ( $n=84$ ) & Patients with SIVH ( $n=70$ ) \\
\hline Mean age, years & $64.4 \pm 0.9$ & $64.4 \pm 1.2$ & $64.5 \pm 1.5$ \\
\hline \multicolumn{4}{|l|}{ Gender: } \\
\hline male, $\mathrm{n}(\%)$ & $88(57.1)$ & $50(59.5)$ & $38(54.3)$ \\
\hline female, $\mathrm{n}(\%)$ & $66(42.9)$ & $34(40.5)$ & $32(45.7)$ \\
\hline \multicolumn{4}{|l|}{ Affected hemisphere: } \\
\hline left, n (\%) & $74(48.1)$ & $40(47.6)$ & $34(48.6)$ \\
\hline right, $\mathrm{n}(\%)$ & $80(51.9)$ & $44(52.4)$ & $36(51.4)$ \\
\hline Admission NIHSS score & $10(6-14)$ & $9(5-12)$ & $12(8-15)$ \\
\hline Admission GCS score & $14(13-15)$ & $15(14-15)$ & $14(12-15)$ \\
\hline Admission FOUR score & $16(14-16)$ & $16(15-16)$ & $15(14-16)$ \\
\hline $\mathrm{ICH}$ volume, $\mathrm{mL}$ & $8.1(2.8-27.7)$ & $6.7(2.6-14)$ & $7.4(3.3-16.4)$ \\
\hline Midline shift, n (\%) & $71(46.1)$ & $29(34.5)$ & $42(60.0)$ \\
\hline Septum pellucidum displacement, $\mathrm{mm}$ & $2.3 \pm 0.3$ & $1.2 \pm 0.3$ & $3.5 \pm 0.4$ \\
\hline Pineal gland displacement, $\mathrm{mm}$ & $1.8 \pm 0.2$ & $1.0 \pm 0.2$ & $2.7 \pm 0.3$ \\
\hline Lethal outcome, $n(\%)$ & $18(11.7)$ & $6(7.1)$ & $13(18.6)$ \\
\hline Unfavourable functional outcome, $\mathrm{n}(\%)$ & $53(34.4)$ & $22(26.2)$ & $31(44.3)$ \\
\hline
\end{tabular}

Table 2. Clinical and neuroimaging characteristics of patients with SSICH and SIVH regarding the outcome of disease in the acute period

\begin{tabular}{|c|c|c|c|c|}
\hline \multirow[t]{2}{*}{ Parameters } & \multicolumn{2}{|l|}{ Vital outcome } & \multicolumn{2}{|l|}{ Functional outcome } \\
\hline & Unfavourable $(n=13)$ & Favourable $(n=57)$ & Unfavourable $(n=31)$ & Favourable $(n=26)$ \\
\hline Admission NIHSS score & $22(17-28)$ & $10(7-14)$ & $13(10-15)$ & $7(4-10)$ \\
\hline Admission GCS score & $10(5-13)$ & $15(14-15)$ & $14(13-15)$ & $15(14-15)$ \\
\hline Admission FOUR score & $13(6-14)$ & $15(15-16)$ & $15(14-16)$ & $16(15-16)$ \\
\hline $\mathrm{SICH}$ volume, $\mathrm{mL}$ & $34.0(25.9-62.3)$ & $7.3(3.1-29.6)$ & $10.8(3.9-30.3)$ & $5.9(3.0-22.0)$ \\
\hline Midline shift, $\mathrm{n}(\%)$ & $13(100.0)$ & $33(57.9)$ & $24(77.4)$ & $9(34.6)$ \\
\hline Septum pellucidum displacement, $\mathrm{mm}$ & $8.1 \pm 0.9$ & $2.6 \pm 0.4$ & $3.8 \pm 0.6$ & $1.3 \pm 0.4$ \\
\hline Pineal gland displacement, mm & $5.6 \pm 0.8$ & $2.0 \pm 0.3$ & $3.0 \pm 0.4$ & $0.8 \pm 0.3$ \\
\hline SIVH volume, $\mathrm{mL}$ & $54.6(30.0-54.6)$ & $6.1(1.8-13.5)$ & $9.0(3.3-13.5)$ & $3.3(1.8-6.0)$ \\
\hline
\end{tabular}

Table 3. Clinical and neuroimaging characteristics of patients with SSICH without SIVH regarding the outcome of disease in the acute period

\begin{tabular}{|c|c|c|c|c|}
\hline \multirow[t]{2}{*}{ Parameters } & \multicolumn{2}{|l|}{ Vital outcome } & \multicolumn{2}{|l|}{ Functional outcome } \\
\hline & Unfavourable $(n=6)$ & Favourable $(n=78)$ & Unfavourable ( $n=22$ ) & Favourable $(n=56)$ \\
\hline Admission NIHSS score & $13(19-25)$ & $8(5-11)$ & $12(9-14)$ & $7(5-9)$ \\
\hline Admission GCS score & $10(6-12)$ & $15(14-15)$ & $14(12-15)$ & $15(14-15)$ \\
\hline Admission FOUR score & $13(10-14)$ & $16(15-16)$ & $16(14-16)$ & $16(15-16)$ \\
\hline $\mathrm{ICH}$ volume, $\mathrm{mL}$ & $29.2(12.4-41.2)$ & $6.0(2.3-12.9)$ & $8.6(5.2-13.5)$ & $5.1(1.7-12.9)$ \\
\hline Midline shift, n (\%) & $6(100.0)$ & $19(24.5)$ & $11(50.0)$ & $8(14.3)$ \\
\hline Septum pellucidum displacement, $\mathrm{mm}$ & $4.5 \pm 1.6$ & $1.0 \pm 0.2$ & $2.0 \pm 0.6$ & $0.5 \pm 0.2$ \\
\hline Pineal gland displacement, mm & $4.2 \pm 1.7$ & $0.8 \pm 0.2$ & $1.6 \pm 0.6$ & $0.5 \pm 0.2$ \\
\hline
\end{tabular}


Table 4. The neuroimaging parameters informative value in patients with $\mathrm{SSICH}$ and SIVH for the vital outcome prognosis of disease in the acute period determination

\begin{tabular}{l|l|l|l|l|} 
Parameters & AUC & SE & $95 \%$ Cl & P \\
\hline ICH volume & 0.72 & 0.09 & $0.60-0.82$ & 0.0178 \\
\hline Septum pellucidum displacement & 0.89 & 0.04 & $0.80-0.95$ & $<0.0001$ \\
\hline Pineal gland displacement & 0.84 & 0.05 & $0.74-0.92$ & $<0.0001$ \\
Average midline shift & 0.88 & 0.04 & $0.78-0.95$ & $<0.0001$ \\
\hline SIVH volume & 0.94 & 0.04 & $0.86-0.98$ & $<0.0001$ \\
\hline
\end{tabular}

Table 5. The neuroimaging parameters informative value in patients with $\mathrm{SSICH}$ and SIVH for the functional outcome prognosis of disease in the acute period determination

\begin{tabular}{l|l|l|l|l|} 
Parameters & AUC & SE & $95 \%$ CI & P \\
\hline ICH volume & 0.58 & 0.08 & $0.44-0.71$ & 0.3134 \\
\hline Septum pellucidum displacement & 0.75 & 0.06 & $0.62-0.86$ & $<0.0001$ \\
\hline Pineal gland displacement & 0.77 & 0.06 & $0.64-0.82$ & $<0.0001$ \\
Average midline shift & 0.78 & 0.06 & $0.65-0.88$ & $<0.0001$ \\
\hline SIVH volume & 0.71 & 0.07 & $0.58-0.83$ & 0.0027 \\
\hline
\end{tabular}

Table 6. The neuroimaging parameters informative value in patients with $\mathrm{SSICH}$ without SIVH for the vital outcome prognosis determination in the acute period of disease

\begin{tabular}{l|l|l|l|l|}
\hline Parameters & AUC & SE & $95 \%$ CI & P \\
\hline ICH volume & 0.77 & 0.11 & $0.67-0.86$ & 0.0139 \\
Septum pellucidum displacement & 0.88 & 0.05 & $0.79-0.94$ & $<0.0001$ \\
\hline Pineal gland displacement & 0.89 & 0.04 & $0.80-0.95$ & $<0.0001$ \\
Average midline shift & 0.87 & 0.05 & $0.78-0.94$ & $<0.0001$ \\
\hline
\end{tabular}

Table 7. The neuroimaging parameters informative value in patients with SSICH without SIVH for the functional outcome prognosis determination in the acute period of disease

\begin{tabular}{l|l|l|l|l|}
\hline Parameters & AUC & SE & $95 \%$ CI & P \\
\hline ICH volume & 0.62 & 0.07 & $0.50-0.73$ & 0.0846 \\
Septum pellucidum displacement & 0.68 & 0.06 & $0.56-0.78$ & 0.003 \\
\hline Pineal gland displacement & 0.67 & 0.06 & $0.55-0.77$ & 0.0052 \\
Average midline shift & 0.67 & 0.06 & $0.55-0.77$ & 0.0047 \\
\hline
\end{tabular}

IVH volume in patients with SIVH for the vital outcome prognosis of disease in the acute period determination $\left(\mathrm{AUC}_{\mathrm{ICHV}}=0.72 \pm 0.09(0.60-0.82)\right.$ versus $\left.\mathrm{AUC}_{\mathrm{IVHV}}=0.94 \pm 0.04(0.86-0.98), \mathrm{P}=0.026\right)$ and did not differ from the average midline shift $\left(\mathrm{AUC}_{\mathrm{ICHV}}=0.72 \pm 0.09\right.$ $(0.60-0.82)$ versus $A_{U} C_{\text {AMs }}=0.88 \pm 0.04(0.78-0.95)$, $\mathrm{P}=0.104)$, whereas $\mathrm{ICH}$ volume was not informative for the functional outcome prognosis of disease in the acute period determination $\left(\mathrm{AUC}_{\mathrm{ICHV}}=0.58 \pm 0.08(0.44-0.71)\right.$, $\mathrm{P}=0.3134)$. However, the informative value of SIVH volume for vital prognosis determination was higher than the one used for the functional prognosis verification $(0.94 \pm 0.04$ (0.86-0.98) versus $0.71 \pm 0.07(0.58-0.83), P=0.004)$. On the basis of ROC analysis it has been detected, that IVHV $>24.5 \mathrm{~mL}$ is the predictor of SSICH lethal outcome in the acute period $(\mathrm{Se}=84.6 \%, \mathrm{Sp}=96.5 \%$; OR $95 \%$ $\mathrm{Cl}=1.18$ (1.07-1.30), $\mathrm{P}=0.0007$ ).

The results of neuroimaging parameters informative value assessment for the vital and functional outcomes prognosis determination in patients with $\mathrm{SSICH}$ without SIVH in the acute period are displayed in Tables 6 and 7.
Based on the comparative ROC analysis it was determined that the informative value of $\mathrm{ICH}$ volume and average midline shift were not significantly different in patients without SIVH for vital $\left(\mathrm{AUC}_{\mathrm{ICHV}}=0.77 \pm 0.11(0.67-0.86)\right.$ versus $\left.A_{\text {AUS }}=0.87 \pm 0.05(0.78-0.94), P=0.257\right)$ and functional outcomes prognosis $\left(\mathrm{AUC}_{\mathrm{ICHV}}=0.62 \pm 0.07\right.$ $(0.50-0.73)$ versus $A U_{\text {AMs }}=0.67 \pm 0.06(0.55-0.77)$, $P=0.423$ ) determination in the acute period of disease. At the same time, the informative value of average midline shift for vital prognosis determination was higher than the one used for functional prognosis verification in patients without SIVH $(0.87 \pm 0.05(0.78-0.94)$ versus $0.67 \pm 0.06$ (0.55-0.77), $P=0.01)$.

\section{Discussion}

As a result of the study it has been determined that the predictive values of $\mathrm{ICH}$ and $\mathrm{AMS}$ in patients with $\mathrm{SSICH}$ are different depending on the SIVH presence or absence. Thus, in patients without SIVH the most informative neuroimaging parameters for the vital outcome prognosis in the acute period of disease determination are the values of septum pellucidum displacement $(0.88(0.79-0.94), \mathrm{P}<0.0001)$ and pineal gland displacement $(0.89(0.80-0.95), P<0.0001)$, as well as ICHV $(0.77(0.67-0.86), P<0.0001)$, which is a little less informative. In our opinion, a higher prognostic value of septum pellucidum displacement in comparison with pineal gland displacement for the vital prognosis determination is not only due to ICHV influence, but also to the perifocal edema severity and its influence on the outcome of disease in the acute period. The obtained data are consistent with the results of other studies in which the leading role of the primary mechanisms of brain damage (including dislocation syndrome) in the lethal outcome of SSICH in the acute period was proved $[9,10,13]$.

The informative value of $\mathrm{ICH}$ volume in patients with SIVH is inferior to that of IVH volume and AMS as for the vital and functional outcomes prognosis of SSICH in the acute period determination, which accords with the results of other studies which have proved the negative influence of SIVH presence and severity on the SSICH course and outcome in the acute period $[5,13,17]$. Our study has determined critical value of IVHV (>24.5 mL), which is the predictor of $\mathrm{SSICH}$ lethal outcome in the acute period ( $\mathrm{Se}=84.6 \%$, $\mathrm{Sp}=96.5 \%$; OR $95 \% \mathrm{Cl}=1.18(1.07-1.30), \mathrm{P}=0.0007)$.

However, regardless of the SIVH presence or absence, the neuroimaging parameters informative value for the functional outcome prognosis verification in the acute period of $\mathrm{SSICH}$ is statistically lower than the one for vital prognosis verification (AUC 0.58-0.78 versus 0.72-0.94, $\mathrm{P}<0.05-$ in patients with SIVH; AUC 0.62-0.67 versus $0.77-0.87$, $\mathrm{P}<0.05$ - in patients without SIVH). In our opinion it is not only due to the influence of primary mechanisms of brain damage on the functional outcome of $\mathrm{SSICH}$ in the acute period, but also to the secondary ones (thrombin-induced inflammatory activation).

Thus, in the prognostic value assessment, it is necessary to take into consideration the SIVH presence or absence. In order to determine the short-term vital and functional prognosis in patients with SSICH and SIVH, it is reasonable to detect the IVHV. 


\section{Conclusions}

1. Predictive value of the neuroimaging parameters at SSICH onset depends on SIVH presence or absence. Intracerebral hemorrhage volume is less informative than intraventricular hemorrhage volume and midline shift for the vital and functional outcomes prognosis determination in the acute period of SSICH with SIVH $\left(\mathrm{AUC}_{\mathrm{ICHV}}=0.72 \pm 0.09\right.$ $(0.60-0.82)$ versus $A U C_{\mathrm{IVHV}}=0.94 \pm 0.04(0.86-0.98)$, $\mathrm{P}=0.026)$.

2. Intraventricular hemorrhage volume $>24.5 \mathrm{~mL}$ is the predictor of SSICH with lethal outcome in the acute period $(\mathrm{Se}=84.6 \%, \mathrm{Sp}=96.5 \%$; OR $95 \% \mathrm{Cl}=1.18$ (1.07-1.30), $P=0.0007$ ).

3. The informative value of intracerebral hemorrhage volume and average midline shift does not significantly differ for the vital $\left(\mathrm{AUC}_{\mathrm{ICHV}}=0.77 \pm 0.11(0.67-0.86)\right.$ versus $\left.\mathrm{AUC}_{\text {AMS }}=0.87 \pm 0.05(0.78-0.94), \mathrm{P}=0.257\right)$ and functional outcomes prognosis determination $\left(\mathrm{AUC}_{\mathrm{ICHV}}=0.62 \pm 0.07\right.$ $(0.50-0.73)$ versus $A U C_{\text {AMS }}=0.67 \pm 0.06(0.55-$ $0.77), P=0.423$ ) in the acute period of $\mathrm{SSICH}$ without SIVH.

4. The informative value of neuroimaging parameters for the vital outcome prognosis determination of SSICH in the acute period is higher than the one for the functional prognosis determination (AUC 0.72-0.94 versus 0.58-0.78, $\mathrm{P}<0.05$ - in patients with SIVH; AUC $0.77-0.87$ versus $0.62-0.67, \mathrm{P}<0.05-$ in patients without SIVH).

The perspective for the further scientific research is the development of differential predictive criteria for $\mathrm{SSICH}$ in patients regarding the SIVH presence or absence.

\section{Фінансування}

АосліАження виконане в рамках НАР Запорізького Аержавного медичного університету "Оптимізація Аіагностичних та мікувально-реабілітаційних заходів у хворих з гострими і хронічними порушеннями мозкового кровообігу" № Аержреєстрації 0113U000798 (2013-2017).

Conflicts of Interest: author has no conflict of interest to declare. Конфмікт інтересів: віАсутній.

Information about author:

Kuznietsov A. A., MD, PhD, Associate Professor of the Department of Nervous Diseases, Zaporizhzhia State Medical University, Ukraine.

Відомості про автора:

Кузнєцов А. А., канА. меА. наук, Аоцент каф. нервових хвороб, Запорізький державний меАичний університет, Україна.

\section{Сведения об авторе:}

Кузнецов А. А., канА. меА. наук, Аоцент каф. нервных болезней, Запорожский государственный меАицинский университет, Украина.

Надійшла Ао редакції / Received: 15.05.2018

Після Аоопрацювання / Revised:22.05.2018

Прийнято Ао Аруку / Accepted: 29.05.2018

\section{References}

[1] Ministerstvo okhorony zdorovia Ukrayiny (2014). Unifikovanyi klinichnyi protokol ekstrenoi, pervynnoi, vtorynnoi (spetsializovanoi), tretynnoi (vysokospetsializovanoi) medychnoi dopomohy ta medychnoi reabilitatsii «Hemorahichnyi insult (vnutrishnomozkova hematoma, anevryzmalnyi subarakhnoidalnyi krovovylyv) [Unified clinical protocol of emergency, primary, secondary (specialized), tertiary (highly specialized) medical care and medical rehabilitation "Hemorrhagic stroke (intrahepatic hematoma, aneurysmal subarachnoid hemorrhage)]. Retrieved from http://moz.gov.ua/docfiles/dod275_ukp_2014.pdf.

[2] Belur, P. K., Chang, J. J., He, S., Emanuel, B. A., \& Mack, W. J. (2013) Emerging experimental therapies for intracerebral hemorrhage: targeting mechanisms of secondary brain injury. Neurosurg Focus, 34(5), E9. doi: 10.3171/2013.2.FOCUS1317.

[3] Feigin, V. L., Krishnamurthi, R. V., Parmar, P., Norrving, B., Mensah, G. A., Bennett, D. A., et al. (2015) Update on the Global Burden of Ischemic and Hemorrhagic Stroke in 1990-2013: The GBD 2013 Study. Neuroepidemiology, 45(3), 161-76. doi: 10.1159/000441085.

[4] Gaberel, T., Magheru, C., Parienti, J. J., Huttner, H. B., Vivien, D., \& Emery, E. (2011) Intraventricular fibrinolysis versus external ventricular drainage alone in intraventricular hemorrhage: a meta-analysis. Stroke, 42(10), 2776-2781. doi: 10.1161/STROKEAHA.111.615724.

[5] Hanley, D. F. (2009) Intraventricular hemorrhage: everity factor and treatment target in spontaneous intracerebral hemorrhage. Stroke, 40(4), 1533-1538. doi: 10.1161/STROKEAHA.108.535419.

[6] Keep, R. F., Hua, Y., \& Xi, G. (2012) Intracerebral haemorrhage: mechanisms of injury and therapeutic targets. Lancet Neurol, 11(8), 720-31. doi: 10.1016/S1474-4422(12)70104-7.

[7] Khan, N. R., Tsivgoulis, G., Lee, S. L., Jones, G. M., Green, C. S., Katsanos, A. H., et al. (2014) Fibrinolysis for intraventricular hemorrhage: an updated meta-analysis and systematic review of the literature. Stroke, 45(9), 2662-2669. doi: 10.1161/STROKEAHA.114.005990.

[8] Newton, J. N., Briggs, A. D., Murray, C. J., Dicker, D., Foreman, K. J., Wang, H., et al. (2015) Changes in health in England, with analysis by English regions and areas of deprivation, 1990-2013: a systematic analysis for the Global Burden of Disease Study 2013. Lancet, 386(10010), 2257-74. doi: 10.1016/S0140-6736(15)00195-6.

[9] Panchal, H. N., Shah, M. S., \& Shah, D. S. (2015) Intracerebral Hemorrhage Score and Volume as an Independent Predictor of Mortality in Primary Intracerebral Hemorrhage Patients. Indian J Surg, 77(2), 302-304. doi: 10.1007/s12262-012-0803-2.

[10] Ozdinc, S., Unlu, E., Karakaya, Z., Turamanlar, O., Dogan, N., Isler, Y., et al. (2016) Prognostic value of perihematomal edema area at the initial ED presentation in patients with intracranial hematoma. Am J Emerg Med., 34(7), 1241-1246. doi: 10.1016/j.ajem.2016.03.048.

[11] Roth, G. A., Forouzanfar, M. H., Moran, A. E., Barber, R., Nguyen, G., Feigin, V. L., et al. (2015) Demographic and epidemiologic drivers of global cardiovascular mortality. New England Journal of Medicine, 372(14), 1333-1341. doi: 10.1056/NEJMoa1406656.

[12] Steiner, T., Al-Shahi Salman, R., Beer, R., Christensen, H., Cordonnier, C., Csiba, L., et al. (2014) European Stroke Organisation (ESO) guidelines for the management of spontaneous intracerebral hemorrhage. Int J Stroke, 9(7), 840-855. doi: 10.1111/ijs.12309.

[13] Specogna, A. V., Turin, T. C., Patten, S. B., \& Hill, M. D. (2014). Factors associated with early deterioration after spontaneous intracerebral hemorrhage: a systematic review and meta-analysis. PLoS One, 9(5), e96743. doi: 10.1371/journal.pone.0096743.

[14] Tao, C., Hu, X., Li, H., \& You, C. (2017) White Matter Injury after Intracerebral Hemorrhage: Pathophysiology and Therapeutic Strategies. Front Hum Neurosci, 25(11), 422. doi: 10.3389/fnhum.2017.00422.

[15] Wendy, C. Z. (2013) Hematology and Inflammatory Signaling of Intracerebral Hemorrhage. Stroke, 44, 74-78. doi: 10.1161/STROKEAHA.111.000662

[16] Wong, R. H., \& Bailes, J. E. (2013) Thrombolysis for intraventricular hemorrhage. Semin Thromb Hemost, 39(4), 400-405.

[17] Ye, Z., Ai, X., Hu, X., Fang, F., \& You, C. (2017). Clinical features and prognostic factors in patients with intraventricular hemorrhage caused by ruptured arteriovenous malformations. Medicine (Baltimore), 96(45), e8544. doi: $10.1097 / M D .0000000000008544$.

[18] Zhou, Y., Wang, Y., Wang, J., Anne Stetler R., \& Yang, Q. W. (2014) Inflammation in intracerebral hemorrhage: from mechanisms to clinical translation. Prog Neurobiol., 115, 25-44. doi: 10.1016/j.pneurobio.2013.11.003. 